\title{
Profile for Body Fat Percentage of Serbian Working Population, Aged from 18 to 65, Measured by Multichannel Bioimpedance Method
}

\author{
Perfil del Porcentaje de Grasa Corporal de la Población Activa Serbia, \\ de 18 a 65 Años, Medido por el Método de Bioimpedancia Multicanal
}

\author{
Milivoj Dopsaj ${ }^{1,4}$; Zoran Pajic ${ }^{1}$; Anastasija Kocic ${ }^{1}$; Marko Erak ${ }^{1}$; Aleksandar Pajkic ${ }^{1,2}$; \\ Aleksandar Vicentijevic ${ }^{1}$; Milos Milosevic ${ }^{1,3}$ \& Branislav Bozovic ${ }^{1}$
}

DOPSAJ, M.; PAJIC, Z.; KOCIC, A.; ERAK, M.; PAJKIC, A.; VICENTIJEVIC, A.; MILOSEVIC, M. \& BOZOVIC, B. Profile for body fat percentage of Serbian working population, aged from 18 to 65 , measured by multichannel bioimpedance method. Int. $J$. Morphol., 39(6):1694-1700, 2021.

SUMMARY: Obesity prevalence and trends of PBF related to age were defined on a sample of 8100 people among whom, 4955 were male $(\mathrm{Age}=31.2 \pm 10 \mathrm{yr})$ and 3145 were female $(\mathrm{Age}=32.1 \pm 11.3 \mathrm{yr})$. Body structure measurements were performed using a standardized method of multichannel bioimpedance analysis (BIA), using a body structure analyzer - InBody 720 . The total sample was divided into two subsamples according to sex, where every subsample was divided into five different age groups. The mean PBF values of the Male total sample were $18.2 \pm 8.0 \%$ and the female total sample was $28.3 \pm 9.2 \%$. Results of Kruskal-Wallis ANOVA with Dwass-Steel-Critchlow-Fligner post-hock showed that there are statistically significant differences $(p<0.001)$ between all age groups among themselves except groups $50-60$ and $60-65(\mathrm{p}=0.09)$. Analysis of obesity prevalence according to the PBF indicator in different age groups revealed the existence of statistically significant $(\mathrm{p}<0.001)$ trends of increasing obesity with age, both in men and women. Based on the result of this study, it can be concluded that most of the Serbian working population are in the range of normal PBF values, excluding the male 30-39.9 yr and female 60-65 yr age categories as groups which are more prone to obesity levels.

KEY WORDS: Obesity; Prevalence; Body Composition; Body Structure.

\section{INTRODUCTION}

It is well known that the modern lifestyle is characterized by sedentariness and insufficient physical activity (Rakic et al., 2019). The increasing use of new technologies has been one of the main factors influencing the reduction of physical activity, which indirectly affects the overall health status, where non-communicable diseases are concerned. By reducing the energy consumption during work, daily overall consumption is also reduced considering the fact that today's working hours often get extended (Torres \& Nowson, 2007). When unhealthy eating habits join in, the result is overweight and obese people, that is, a state where body mass and percentage of body fat are so increased, it can affect overall health status (Friedman, 2009), or other types of specific illnesses such as heart problems (Diehl et al., 2018) or body deformities (Oliveira et al., 2014).
Developing the system for measuring and controlling the status of body composition has become an increasingly popular tool for monitoring the general health status (Gába et al., 2015), or health status of a specific population, such as athletes or policemen, regardless of gender, age or sport type (Dopsaj et al., 2017; Rakic et al.). Besides, defining the model for body composition of a certain population presents expertise in which is decided whether a level of a certain component of body tissue is insufficient, satisfying, or dominantly presented in the body (Rakic et al.). In other words, it is a valuable tool for determining if the effect of treatment exists and how big its impact is, whether if it's a result of physical or dietary treatment (Bellicha et al., 2021). Accordingly, bioelectrical impedance analysis presents one of the most common methods for collecting data about complete body structure and body

\footnotetext{
${ }^{1}$ Faculty of Sport and Physical Education, University of Belgrade, Belgrade, Serbia.

${ }^{2}$ Faculty of Physical Education and Sport, University of Banja Luka, Banja Luka, Bosnia and Herzegovina.

${ }^{3}$ Faculty of Physical Culture and Management in Sport, Singidunum University, Belgrade, Serbia.

${ }^{4}$ SUSU, South Ural State University, Institute of Sport, Tourism and Service, Chelyabinsk, Russia.

This study was funded by the Ministry of Education, Science and Technological Development of the Republic of Serbia - Scientific Project $2011-2020$ as a part of national project, number III 47015 .
} 
segments separately (Dopsaj et al., 2017).

When collecting data about body structure, it is important to interpret it properly. Therefore, racial as well as national differences affect defining the ranges of certain body components (Deurenberg et al., 2001; Gallagher et al., 2000). It is necessary to take these differences into account when such type of study is conducted.

The aim of this study was to define standards for the evaluation of the body structure of the Serbian working population, according to the percentage of body fat (PBF), measured by the multichannel bioimpedance method. Given results can be used as a criterion for evaluation of body structure according to the national population, regarding the sex and various age groups.

\section{MATERIAL AND METHOD}

Subject sample. The sample of this research included 8100 subjects $(\mathrm{Age}=31.5 \pm 10.5 \mathrm{yr}, \mathrm{BH}=176.8 \pm 9.7 \mathrm{~cm}, \mathrm{BM}=$ $79.7 \pm 17.3 \mathrm{~kg}$ ) among whom, 4955 were male (Age $=31.2 \pm$ $10 \mathrm{yr}, \mathrm{BH}=182.1 \pm 7.2 \mathrm{~cm}, \mathrm{BM}=87.4 \pm 14.8 \mathrm{~kg})$ and 3145 were female $(\mathrm{Age}=32.1 \pm 11.3 \mathrm{yr}, \mathrm{BH}=168.4 \pm 7.1 \mathrm{~cm}, \mathrm{BM}$ $=67.7 \pm 13.7 \mathrm{~kg}$ ).

All respondents have been informed of research goals and gave their voluntary consent to participate in it. The research was carried out in accordance with the postulates of the Helsinki Declaration and with the approval of the Ethics Commission of the Faculty of sport and physical education, University of Belgrade (Ethics commission permit 484-2).

Methods. Measurements were performed in the 2011 - 2021 period in Methodical Research Laboratory (MRL) "Slobodan Jaric" at the Faculty of sport and physical education, University of Belgrade. Measurements were performed using a standardized method of multichannel $(1,5,50,250,500,1000$ $\mathrm{kHz}$ ) bioimpedance analysis (BIA), using a body structure analyzer - InBody 720 (Biospace Co., Ltd, Seoul, Korea). Body height measurement was performed with an anthropometer (GSM, Swiss-made), while body weight was measured on the mentioned InBody 720 device in accordance with a standardized procedure (Gába et al.). According to WHO recommendations, a subsample of age categories with a correction for the first age group was defined, in relation to the following five age categories: 18 - 29.9; 30 - 39.9; 40 49.9; 50 - 59.9; 60 - 65 years (Dopsaj et al., 2018).

Variables. Percentage of body fat (PBF) is the only indicator of health level that is directly related to body composition, regardless of body height or body weight. The classification of PBF values is taken over from existing standards by Sports Science and World Health Organization in relation to both sexes (Gallagher et al.; Friedman). The reference values of the percentage of adipose tissue are defined in 4 groups: insufficient, normal, overweight, and obese, where the criteria of reference values differ in relation to both sex and age (Gallagher et al.).

Statistics. After data collection and their entry into the numerical matrix, descriptive and analytical statistical analyzes were performed. The standardized nonparametric Kolmogorov-Smirnov test (K-S Z) was used to determine the distribution normality. The non-parametric Kruskal-Wallis test was used to examine differences at the general level in relation to sex and age. Using Dwass-Steel-Critchlow-Fligner posthock, partial differences were found according to the age of the subjects. The relationship between the variable PBF and the age of the subjects as well as the trends of change in PBF with age in the subsample were treated with non-parametric Spearman's rho method and Jonckheere-Terpstra test. Besides, the prevalence of nutrition categories was calculated by the standard procedure and is expressed in relative values, i.e. in percentages (Dopsaj et al., 2018). Statistical analysis was performed using IBM SPSS 20 software packages (Armonk, NY, United States: IBM Corp).

\section{RESULTS}

Descriptive statistical analysis of PBF was performed for the entire sample as well as subsamples by sex and age (Table I and Fig. 1).

The results of the non-parametric KolmogorovSmirnov test show that there are significant deviations from the normal distribution of the PBF for the total sample as well as for both sex subsamples. That is why it is necessary to apply non-parametric statistics in further analysis.

The non-parametric Kruskal-Wallis ANOVA test (Table II) reveals significant differences in PBF according to sex and age factors. There is a large effect in both factors.

Dwass-Steel-Critchlow-Fligner post-hock showed that there are statistically significant differences $(\mathrm{p}<0.001)$ between all age groups among themselves except groups 50 60 and $60-65(\mathrm{p}=0.09)$.

Sex differences are shown in Figure 1. Trends of change according to sex are shown in Figures 2 and 3, along with prediction models. 
DOPSAJ, M.; PAJIC, Z.; KOCIC, A.; ERAK, M.; PAJKIC, A.; VICENTIJEVIC, A.; MILOSEVIC, M. \& BOZOVIC, B. Profile for body fat percentage of Serbian working population, aged from 18 to 65, measured by multichannel bioimpedance method. Int. J. Morphol., 39(6):1694-1700, 2021.

Table I. Basic descriptive indicators of the PBF of the total sample and sex subsamples.

\begin{tabular}{|c|c|c|c|c|c|c|c|}
\hline \multirow{2}{*}{$\operatorname{PBF}(\%)$} & \multirow{2}{*}{ Age } & \multirow{2}{*}{ Mean (\%) } & \multirow{2}{*}{$\mathrm{SD}(\%)$} & \multirow{2}{*}{$\mathrm{cV}(\%)$} & \multicolumn{2}{|c|}{$95 \%$ Conf. Inter. } & \multirow{2}{*}{$\mathrm{K}-\mathrm{S} \mathrm{Z}$} \\
\hline & & & & & Low. & Upper. & \\
\hline \multirow{6}{*}{ Male } & $18-29.9$ & 14.3 & 6.8 & 0.5 & 14.1 & 14.6 & $0.07 * * *$ \\
\hline & $30-39.9$ & 21.9 & 7.4 & 0.3 & 21.5 & 22.3 & $0.06 * * *$ \\
\hline & $40-49.9$ & 22.6 & 6.4 & 0.3 & 22.1 & 23.1 & $0.05 * *$ \\
\hline & $50-59.9$ & 24.1 & 5.8 & 0.2 & 23.3 & 24.9 & $0.11 * * *$ \\
\hline & $60-65$ & 26.2 & 6.9 & 0.3 & 24.3 & 28.0 & 0.1 \\
\hline & Total & 18.2 & 8.0 & 0.4 & 17.9 & 18.4 & $0.04 * * *$ \\
\hline \multirow{6}{*}{ Female } & $18-29.9$ & 25.5 & 7.9 & 0.3 & 25.1 & 25.9 & $0.07 * * *$ \\
\hline & $30-39.9$ & 28.9 & 9.5 & 0.3 & 28.2 & 29.5 & 0.03 \\
\hline & $40-49.9$ & 32.0 & 8.6 & 0.3 & 31.2 & 32.8 & $0.05 *$ \\
\hline & $50-59.9$ & 36.3 & 8.5 & 0.2 & 35.2 & 37.5 & 0.05 \\
\hline & $60-65$ & 39.3 & 9.8 & 0.2 & 36.9 & 41.6 & $0.13 * *$ \\
\hline & Total & 28.3 & 9.2 & 0.3 & 28.0 & 28.6 & $0.06 * * *$ \\
\hline
\end{tabular}

Descriptive indicators: Mean, Standard Deviation (SD), Coefficient of variation (cV), 95\% confidence interval (95\% Conf. Inter.), Kolmogorov-Smirnov $\mathrm{z}$ value (K-S Z.), *p<0.05, **p $<0.01, * * * \mathrm{p}<0.001$

Results of percentile distribution of PBF and obesity prevalence according to the age subsample categories are presented in Tables III and IV.

Analysis of obesity prevalence according to the PBF indicator (Table III) in different age groups revealed the existence of statistically significant $(\mathrm{p}<0.001)$ trends of increasing obesity with age, both in men and women.

Table II. Results of Kruskal-Wallis ANOVA for the PBF in relation to sex and age.

\begin{tabular}{lcccc}
\hline & $\mathbf{X}_{\mathbf{2}}$ & $\mathbf{d f}$ & $\mathbf{p}$ & $\boldsymbol{\varepsilon}^{\mathbf{2}}$ \\
\hline Sex & 2069 & 1 & $<0.001$ & 0.255 \\
Age & 1348 & 4 & $<0.001$ & 0.166 \\
\hline
\end{tabular}

Chi-square $\left(\mathrm{X}^{2}\right)$, Degrees of freedom (df), Level of statistical significance (p), Effect size $\left(\varepsilon^{2}\right)$

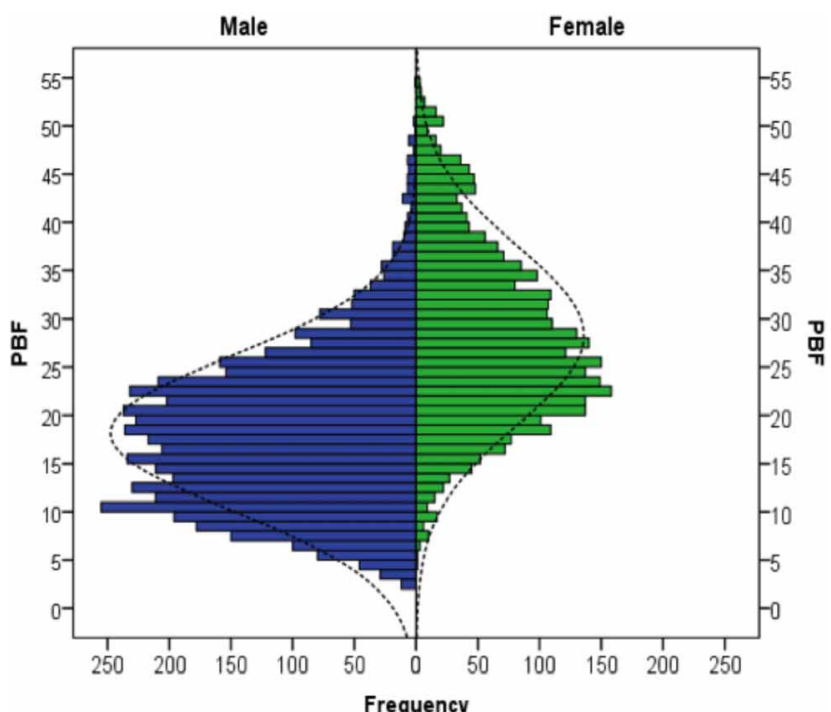

Fig. 1. Distribution of PBF according to the sex differences in population.

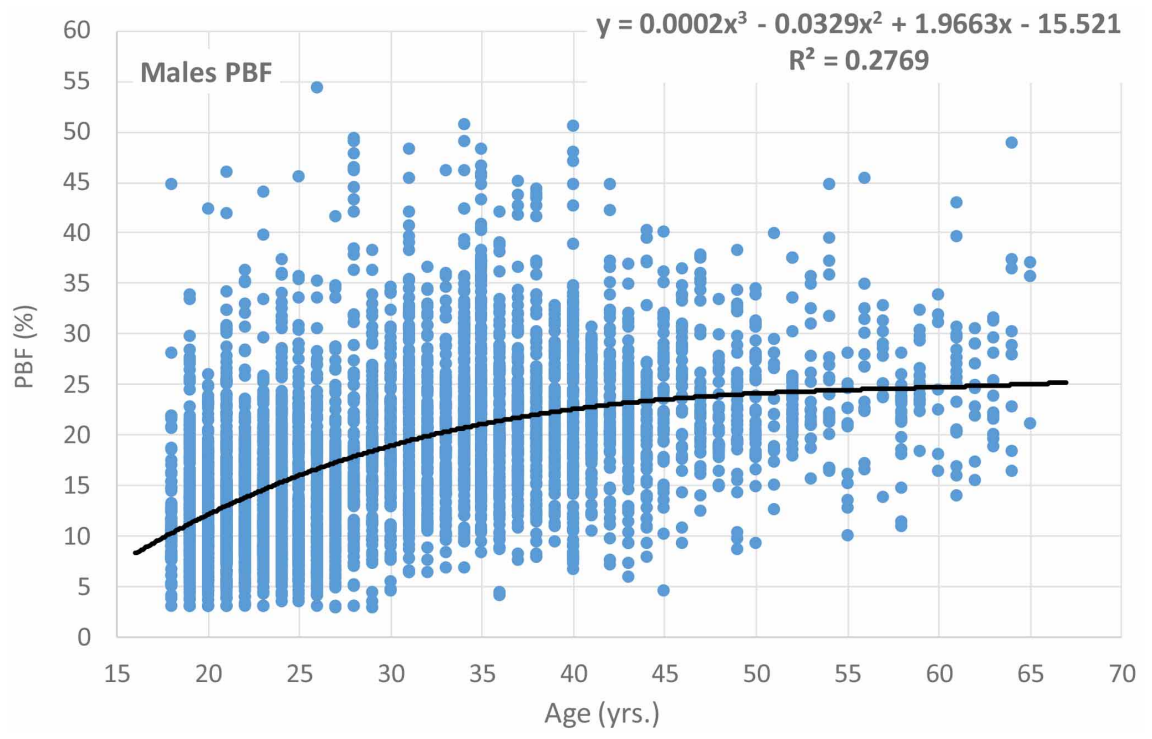

Fig. 2. PBF trend of change in relation to male examined groups. 


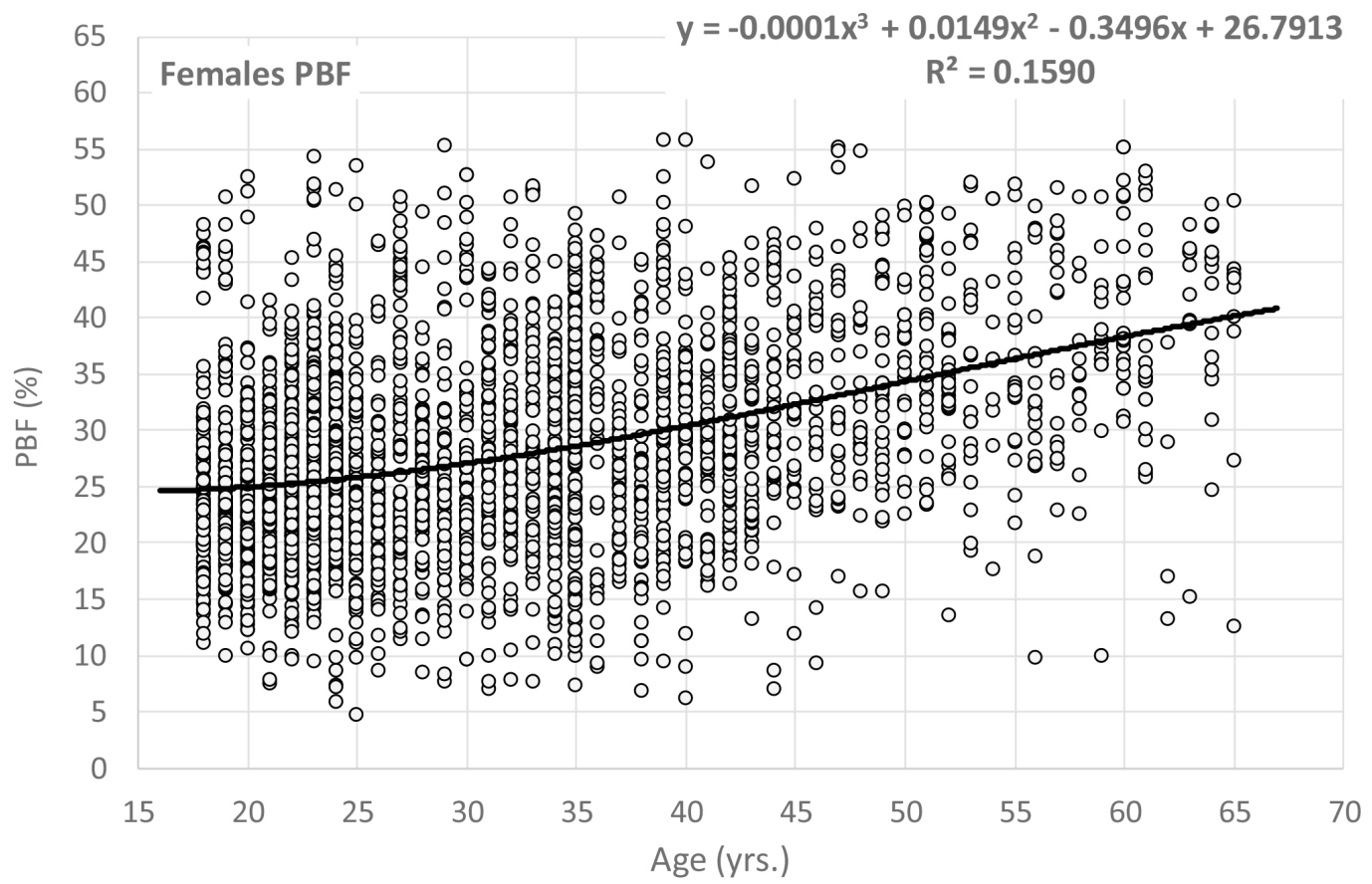

Fig. 3. PBF trend of change in relation to female examined groups.

Table III. Results of percentile distribution of PBF of examined age groups related to sex.

\begin{tabular}{|c|c|c|c|c|c|c|c|c|c|c|}
\hline \multirow{2}{*}{\multicolumn{2}{|c|}{$\begin{array}{l}\text { Variable } \\
\text { PBF (\%) }\end{array}$}} & \multicolumn{9}{|c|}{ Percentile } \\
\hline & & 2.5 & 5.0 & 10.0 & 25.0 & 50.0 & 75.0 & 90.0 & 95.0 & 97.5 \\
\hline \multirow{6}{*}{ Male } & $18-29.9$ & 4.6 & 5.6 & 7.1 & 9.6 & 13.2 & 18.0 & 22.9 & 26.4 & 30.8 \\
\hline & $30-39.9$ & 9.1 & 10.9 & 12.8 & 16.9 & 21.4 & 25.7 & 31.5 & 34.8 & 39.2 \\
\hline & $40-49.9$ & 9.7 & 11.9 & 14.7 & 18.8 & 22.3 & 26.3 & 30.7 & 33.9 & 36.9 \\
\hline & $50-59.9$ & 12.7 & 15.2 & 17.9 & 21.0 & 23.6 & 26.5 & 31.9 & 35.7 & 37.5 \\
\hline & $60-65$ & 14.6 & 15.8 & 17.3 & 21.4 & 25.5 & 29.7 & 36.5 & 39.8 & 46.1 \\
\hline & Total & 5.5 & 6.8 & 8.4 & 11.9 & 17.6 & 23.1 & 28.4 & 32.2 & 35.8 \\
\hline \multirow{6}{*}{ Female } & $18-29.9$ & 12.9 & 14.8 & 16.7 & 20.2 & 24.3 & 29.6 & 35.9 & 41.4 & 45.8 \\
\hline & $30-39.9$ & 10.8 & 13.8 & 16.8 & 22.3 & 28.4 & 34.9 & 41.9 & 44.9 & 47.7 \\
\hline & $40-49.9$ & 16.5 & 18.6 & 21.0 & 25.8 & 31.4 & 38.0 & 43.7 & 46.2 & 48.0 \\
\hline & $50-59.9$ & 18.9 & 22.9 & 26.3 & 30.8 & 35.9 & 42.9 & 47.8 & 50.6 & 51.4 \\
\hline & $60-65$ & 13.0 & 16.0 & 26.1 & 34.3 & 42.0 & 45.9 & 50.5 & 52.3 & 53.7 \\
\hline & Total & 12.9 & 15.0 & 17.6 & 21.6 & 27.1 & 34.2 & 41.8 & 45.6 & 48.2 \\
\hline
\end{tabular}

Table IV. Obesity prevalence for the variable PBF in relation to sex and age.

\begin{tabular}{|c|c|c|c|c|c|}
\hline & \multirow[b]{2}{*}{ Age } & \multicolumn{4}{|c|}{ PBF categories } \\
\hline & & Insufficient & Normal & Overweight & Obese \\
\hline \multirow{5}{*}{ Male } & $18-29.9$ & $11.2 \%$ & $71.9 \%$ & $10.2 \%$ & $6.7 \%$ \\
\hline & $30-39.9$ & $0.7 \%$ & $40.1 \%$ & $30.9 \%$ & $28.3 \%$ \\
\hline & $40-49.9$ & $2.6 \%$ & $44.6 \%$ & $36.2 \%$ & $16.5 \%$ \\
\hline & $50-59.9$ & $1.5 \%$ & $63.1 \%$ & $20.7 \%$ & $14.6 \%$ \\
\hline & $60-65$ & $0.0 \%$ & $46.6 \%$ & $31.0 \%$ & $22.4 \%$ \\
\hline \multirow{5}{*}{ Female } & $18-29.9$ & $26.2 \%$ & $58.2 \%$ & $9.0 \%$ & $6.6 \%$ \\
\hline & $30-39.9$ & $21.3 \%$ & $46.5 \%$ & $17.5 \%$ & $14.8 \%$ \\
\hline & $40-49.9$ & $14.2 \%$ & $44.7 \%$ & $22.8 \%$ & $18.3 \%$ \\
\hline & $50-59.9$ & $6.1 \%$ & $44.3 \%$ & $21.2 \%$ & $28.3 \%$ \\
\hline & $60-65$ & $6.0 \%$ & $26.9 \%$ & $16.4 \%$ & $50.7 \%$ \\
\hline
\end{tabular}


DOPSAJ, M.; PAJIC, Z.; KOCIC, A.; ERAK, M.; PAJKIC, A.; VICENTIJEVIC, A.; MILOSEVIC, M. \& BOZOVIC, B. Profile for body fat percentage of Serbian working population, aged from 18 to 65, measured by multichannel bioimpedance method. Int. J. Morphol., 39(6):1694-1700, 2021.

\section{DISCUSSION}

Within the present study, we defined obesity prevalence of the Serbian working population, according to the percentage of body fat (PBF), measured by the multichannel bioimpedance method. Obtained results can be used as a criterion for evaluation of body structure according to the national population, regarding the sex and various age groups.

According to the National Institutes of Health (2008), basic descriptive indicators of the PBF for total sample values for men are below values for obesity of $25 \%$ (Table I, Mean $\pm \mathrm{SD}=18.2 \pm 8.0 \%$ ), while male subsample aged 60 - 65 have average PBF over obesity values of $25 \%$ (Table I, Mean $\pm \mathrm{SD}=26.2 \%$ ). Regarding gender, the total sample values for women are below values of the PBF for obesity of $35 \%$ (Table I, Mean $\pm \mathrm{SD}=28.3 \pm 9.2 \%$ ), while female subsamples aged over 49.9 years are over obesity values (Table I, from $36.3 \%$ to $39.3 \%$ ). Average values of PBF of the whole sample indicate that the Serbian working population from 18 to 65 years, does not belong to the obese population in general, but it is confirmed that PBF increases with age (Table II, K-W ANOVA, $\mathrm{p}<0.001, \varepsilon^{2}=0.166$ ). Furthermore, values of PBF for men and women are lower in regard to Turkish (25.9 and 37.9) and United Kingdom (22.9 and 35.5) men and women (Bozkirli et al., 2007; Flint et al., 2014). One reason for these differences could be a slightly older average age of samples in these two studies, although this can be related to different eating habits which are part of different national traditional food (Trichopoulou et al., 2007).

The findings of this study were that PBF substantially varied depending on age and sex. The study reported that males had a significantly lower PBF than females (Table II, $\mathrm{K}-\mathrm{W}$ ANOVA, $\left.\mathrm{p}<0.001, \varepsilon^{2}=0.255\right)$. These findings were consistent with those from previous studies (Hu et al., 2017). Although men generally have lower levels of PBF, some studies report a higher percentage of overweight or obese men (Hu et al.), due to different PBF cutoffs between the sex.

The frequency distribution of PBF according to the gender-related to the Serbian working population (Fig. 1) shows that most of the male population included in this study is distributed between $10 \%$ and $25 \%$, while most of the female population was between $20 \%$ and $30 \%$. Regression analysis showed that in men over 18 years of age, PBF increases $3.952 \%$ over one decade, respectively (Fig. 2), and this regression model explains 24.5 percent of the total trend variance (Fig. 2), while in women PBF increases
$3.214 \%$ over one decade, respectively (Fig. 3) and this regression model explains only $15.6 \%$ of the total trend variance. Since only $1 / 4$ of the male population was explained by the equation model (Fig. 2, PBF $=0.3952$ age group +5.8325 ) and less than $1 / 6$ of the female population was explained by the equation model (Fig. 3, PBF $=0.3214$ age group +17.975 ) it could be pointed out that there are numerous factors influencing the body structure in relation to the body fat. Recent research shows that female body status is significantly changed, especially after 30 years, considering the different social and health factors (Rakic et $a l$.), also, an important relationship could exist between PBF increase related to $\mathrm{BMI}$, according to the previous research (Dopsaj et al. 2020). In another research, conducted on Belgrade University (BU) students (Dopsaj et al., 2015) similar body characteristics were measured. In the case of PBF observation, there are slight differences compared to the results of this study. PBF of BU students are slightly lower comparing to this study (PBF Male, $12.9 \pm 6.0$ vs $14.3 \pm$ 6.8 ; Female, $23.8 \pm 6.5$ vs $25.5 \pm 7.9$ ). There are some limitations that affect these results such as a wider age range in this study subsample (18 - 29.9 years) which includes the older population in relation to the previously mentioned research and greater sample. In accordance with limitations, it could be assumed that BU students do not differ significantly from the overall population, regarding the PBF.

Obesity prevalence showed that women older than 60 (Table IV, $50.7 \%$ ) and men age 30 - 40 (Table IV, 28.3 $\%$ ), as well as 60 - 65 (Table IV, $22.4 \%$ ), are groups at greater risk of obesity in a population of Serbian adults.The $\mathrm{PBF}$ is the only indicator of health level that is directly related to body composition, regardless of body height or body weight (Escobedo-de la Peña et al., 2020; Pribis et al., 2010). Even in adults who had a normal BMI but high PBF, it was found a significantly higher prevalence of high blood pressure (men only), hyperglycemia, and dyslipidemia (Kim et al. 2013). Considering the geriatric population, a recent study (Mikkola et al., 2020) concluded that in older adults, higher fat mass is, independently of lean mass, associated with lower physical health-related quality of life and greater decline in health-related quality of life. They recommended that prevention of adiposity may contribute to the preservation of a good quality of life in older age. Also, the younger population of people should be careful, as overweight and obesity in young adulthood are associated with an increased risk of stroke, according to Guo et al. (2016). The risk effect gradually increases with increasing body weight. Based on the result of this study, it can be concluded that most of the Serbian working population are in the range of normal PBF values, excluding the male 30 $39.9 \mathrm{yr}$ and female 60 - $65 \mathrm{yr}$ age categories as groups which are more prone to obesity. 


\section{ACKNOWLEDGEMENTS}

This study was the part of the national project "Effects of applied physical activity on the locomotor, metabolic, psychosocial and educational status of the population of the Republic of Serbia”, project number III47015, funded by the Ministry of Education, Science and Technological Development of the Republic of Serbia - Scientific Project $2011-2020$.

DOPSAJ, M.; PAJIC, Z.; KOCIC, A.; ERAK, M.; PAJKIC, A.; VICENTIJEVIC, A.; MILOSEVIC, M. \& BOZOVIC, B. Perfil del porcentaje de grasa corporal de la población activa serbia, de 18 a 65 años, medido por el método de bioimpedancia multicanal. Int. J. Morphol., 39(6):1694-1700, 2021.

RESUMEN: La prevalencia de obesidad y las tendencias de PBF relacionadas con la edad se determinaron en una muestra de 8100 personas, de las cuales 4955 eran hombres (Edad $=31,2 \pm 10$ años) y 3145 eran mujeres (Edad $=32,1 \pm 11,3$ años). Las mediciones de la estructura corporal se realizaron utilizando un método estandarizado de análisis de bioimpedancia multicanal (BIA), usando un analizador de estructura corporal - InBody 720. La muestra total se dividió en dos submuestras, según el sexo, donde cada muestra se dividió en cinco grupos de edad diferentes. Los valores de PBF de la muestra total masculina fueron 18,2 $\pm 8,0 \%$ y la muestra total femenina fue $28,3 \pm 9,2 \%$. Los resultados del ANOVA de Kruskal-Wallis con Dwass-Steel-CritchlowFligner post-corvejón mostraron que existían diferencias estadísticamente significativas $(\mathrm{p}<, 001)$ entre todos los grupos de edad, excepto los grupos 50 - 60 y $60-65$ (p = 0.09). El análisis de la prevalencia de obesidad según el indicador PBF en diferentes grupos de edad, reveló la existencia de tendencias estadísticamente significativas $(\mathrm{p}<0,001)$ de un aumento de la obesidad con la edad, tanto en los hombres como en las mujeres. Con base en el resultado de este estudio, se puede concluir que la mayoría de la población activa de Serbia se encuentra en el rango de valores normales de PBF, excluyendo las categorías de edad de hombres de 30 a 39,9 años y de mujeres de 60 a 65 años, como los grupos que son más propensos a los niveles de obesidad.

PALABRAS ClAVE: Obesidad; Prevalencia; Composición corporal; Estructura corporal.

\section{REFERENCES}

Bellicha, A.; van Baak, M. A.; Battista, F.; Beaulieu, K.;Blundell, J. E.; Busetto, L.; Carraça, E. V.; Dicker, D.; Encantado, J.; Ermolao, A.; Farpour-Lambert, N.; Pramono, A.; Woodward, E. \& Oppert, J. M. Effect of exercise training on weight loss, body composition changes, and weight maintenance in adults with overweight or obesity: An overview of 12 systematic reviews and 149 studies. Obes. Rev., 22 Suppl 4(Suppl 4):e13256. 2021.
Bozkirli, E.; Ertorer, M. E.; Bakiner, O.; Tutuncu, N. B. \& Demirag, N. G. The validity of the World Health Organisation's obesity body mass index criteria in a Turkish population: a hospital-based study. Asia Pac. J. Clin. Nutr., 16(3):443-7, 2007.

Deurenberg, P.; Andreoli, A.; Borg, P.; Kukkonen-Harjula, K.; De Lorenzo, A.; Van Marken Lichtenbelt, W. D.; Testolin, G.; Vigano, R. \& Vollaard, N. The validity of predicted body fat percentage from body mass index and from impedance in samples of five European populations. Eur. J. Clin. Nutr., 55(11):973-9, 2001.

Diehl, K.; Fuchs, A. K.; Rathmann, K. \& Hilger-Kolb, J. Students' motivation for sport activity and participation in university sports: A mixed-methods study. BioMed Res. Int., 2018(1):1-8, 2018.

Dopsaj, M.; Dordevic-Nikic, M.; Hafizova, A.; Eminovic, F.; Markovic, S.; Yanchik, E. \& Dopsaj, V. Structural body composition profile and obesity prevalence at female students of the university of belgrade measured by multichannel bioimpedance protocol. Hum. Sport Med.., 20(2):53-62, 2020.

Dopsaj, M.; Ilic, V.; Dordevic-Nikic, M.; Vukovic, M.; Eminovic, F.; Macura, M. \& Ilic, D. Descriptive model and gender dimorphism of body structure of physically active students of Belgrade University: Pilot study. Anthropol., 19(1):239-48, 2015.

Dopsaj, M.; Markovic, M.; Kasum, G.; Jovanovic, S.; Koropanovski, N.; Vukovic, M. \& Mudric, M. Discrimination of different body structure indexes of elite athletes in combat sports measured by multi frequency bioimpedance method. Int. J. Morphol., 35(1):99-207, 2017.

Dopsaj, M.; Markovic, S.; Jovanovic, J.; Vukovic, V.; Maksimovic, M.; Miljus, D.; Tomanic, M.; Anicic, Z.; Tomic, L. \& Stankovic, A. BMI: Analysis of the population indicators in working population of the Republic of Serbia in relation to gender and age. Fiz. kult., 72(2):148$60,2018$.

Escobedo-de la Peña, J.; Ramírez-Hernández, J. A.; Fernández-Ramos, M. T.; González-Figueroa, E. \& Champagne, B. Body fat percentage rather than body mass index related to the high occurrence of type 2 diabetes. Arch. Med. Res., 51(6):564-71, 2020.

Flint, E.; Cummins, S. \& Sacker, A. Associations between active commuting, body fat, and body mass index: population based, cross sectional study in the United Kingdom. Br. Med. J., 349:g4887, 2014.

Friedman D. Physical inactivity: a global public health problem. In: Brukner, P.; Khan, K. eds. Brukner \& Khan's Clinical Sports Medicine: The Medicine of Exercise, Vol. 2, 5e. McGraw Hill; 2019. https:// csm. mhmedical.com/content aspx ?bookid=2667\&sectionid=224521505.

Gába, A.; Kapus, O.; Cuberek, R. \& Botek, M. Comparison of multiand single-frequency bioelectrical impedance analysis with dualenergy X-ray absorptiometry for assessment of body composition in post-menopausal women: Effects of body mass index and accelerometer-determined physical activity. J. Hum. Nutr. Diet., 28(4):390-400, 2015.

Gallagher, D.; Heymsfield, S. B.; Heo, M.; Jebb, S. A.; Murgatroyd, P. R. \& Sakamoto, Y. Healthy percentage body fat ranges: An approach for developing guidelines based on body mass index. Am. J. Clin. Nutr., 72(3):694-701, 2000.

Guo, Y.; Yue, X. J.; Li, H. H.; Song, Z. X.; Yan, H. Q.; Zhang, P.; Gui, Y. K.; Chang, L. \& Li, T. Overweight and obesity in young adulthood and the risk of stroke: Ameta-analysis. J. Stroke Cerebrovasc. Dis., 25(12):29953004,2016

Hu, L.; Huang, X.; You, C.; Li, J.; Hong, K.; Li, P.; Wu, Y.; Wang, Z.; Gao, R.; Bao, H. \& Cheng, X. Prevalence of overweight, obesity, abdominal obesity and obesity-related risk factors in southern China. PLOS ONE, 12(9):e0183934, 2017.

Kim, J. Y.; Han, S. H. \& Yang, B. M. Implication of high-body-fat percentage on cardiometabolic risk in middle-aged, healthy, normal-weight adults. Obesity, 21(8):1571-7, 2013.

Mikkola, T. M.; Kautiainen, H.; von Bonsdorff, M. B.; Salonen, M. K.; Wasenius, N.; Kajantie, E. \& Eriksson, J. G. Body composition and changes in health-related quality of life in older age: a 10-year follow-up of the Helsinki Birth Cohort Study. Qual. Life Res., 29(8):2039-50, 2020. 
DOPSAJ, M.; PAJIC, Z.; KOCIC, A.; ERAK, M.; PAJKIC, A.; VICENTIJEVIC, A.; MILOSEVIC, M. \& BOZOVIC, B. Profile for body fat percentage of Serbian working population, aged from 18 to 65, measured by multichannel bioimpedance method. Int. J. Morphol., 39(6):1694-1700, 2021.

Oliveira, A.; Jácome, C. \& Marques, A. Physical fitness and exercise training on individuals with spina bifida: A systematic review. Dev. Disabil. Res. Rev., 35(5):1119-36, 2014.

Pribis, P.; Burtnack, C. A.; Mckenzie, S. O. \& Thayer, J. Trends in body fat, body mass index and physical fitness among male and female college students. Nutrients, 2(10):1075-85, 2010.

Rakic, S.; Dopsaj, M.; Djordjevic Nikic, M.; Vasiljevic, N.; Dopsaj, V.; Maksimovic, M.; Tomanic S.; M. \& Miljus, D. Profile and reference values for body fat and skeletal muscle mass percent at females, aged from 18.0 to 69.9 , measured by multichannel segmental bioimpedance method: Serbian population study. Int. J. Morphol., 37(4):1286-93, 2019.

Torres, S. J. \& Nowson, C. A. Relationship between stress, eating behavior, and obesity. Nutrition, 23(11-12):887-94, 2007.

Trichopoulou, A.; Soukara, S. \& Vasilopoulou, E. Traditional foods: a science and society perspective. Trends Food Sci. Tech., 18(8):420-7, 2007.

US Department of Health and Human Services. National Institutes of Health. WIN weight control network. Understanding adult obesity. NIH Publication No. 06-3680, 2008.
Corresponding author:

Branislav Bozovic

Faculty of Sport and Physical Education

University of Belgrade

Blagoja Parovica 156a

Belgrade

SERBIA

E-mail: branislav.bozovic.91@gmail.com

Received: 03-07-2021

Accepted: 24-08-2021 